\title{
The challenges and issues of e-government in Indonesia from citizen's perspective
}

\author{
A Endang ${ }^{1^{*}}$ \\ ${ }^{1}$ Information System, Widyatama University, Bandung, Indonesia \\ *amaliaendang@gmail.com
}

\begin{abstract}
Each ministry and local government in Indonesia has a separate service to serve the citizens. But with the e-government ministries and local government should be able to further improve public services for citizens and centralized. In this research will be analyzed on the challenges and issues that occurred in Indonesia from the perspective of service for citizen in order to avoid unnecessary inconvenience and red tape in regard to moving, living, studying, working, shopping or simply travelling abroad. Analyze in this research using qualitative method to describe the current condition of each element especially in challenges and issues that occurs. The groups of services for citizens that analyzed in this research are Travel, Work and Retirement, Vehicles, Residence formalities, Education and Youth, Health, Family consumers which results from this research could leads government to focus on improvements to enhance public services for citizens.
\end{abstract}

\begin{abstract}
1. Introduction
Almost every citizen will deal with government agencies for the purposes of public administration. A wide variety of residence documents and business documents require citizens to interact with government officials at various institutions. Unfortunately, the services provided until now considered not satisfactory. The existence of One Roof Service Unit (UPTSA) at the municipal or district government level, has not provided effective service even far to be communicative. State Service to its citizens is a mandate contained in the 1945 Constitution and clarified again in Law no. 25 of 2009 on Public Service. The Public Service Law sets forth the principles of good governance in order for government functions to be effective. Public services are undertaken by government agencies or counterparties to strengthen democracy and human rights, promote economic prosperity, social cohesion, reduce poverty, improve environmental protection, be wise in the utilization of natural resources, deepen trust in government and public administration. Various public service providers belonging to the government should reflect on past experiences, when many criticisms are directed at improving the quality of public services. Government agencies are always saggy in providing public services. Management of ID cards, Driving License (SIM), Building Permit (IMB), the difficulty of obtaining easy and quality education services, health services that most people cannot afford, etc., are a small part of the example of public servants' messiness. This is certainly against the spirit of reform that has been running for more than a decade. The main factors that hamper good public services can be seen from two sides, namely bureaucracy and public service standards. It is common knowledge that within the body of the Indonesian state government at all levels and types it has a long bureaucratic structure, fat, and convoluted (1).
\end{abstract}




\section{Research Method}

This research conducted investigations the challenges and issues of E-Government in Indonesia seen through the services for citizens. Firstly, the author of this paper searched the important component of the the services for citizens of E-Government in Indonesia by google and found as Travel, Work and retirement, Vehicles, Residence formalities, Education and youth, Health, Family and Consumers (2). and then, the author analyze the challenges and issues of the group above. Secondly, the author of this research focused on this concept, this concept is choose because this concept has complete components to study this research. Thirdly, the author collect the data related to this concept. Including the responsibility, website, description of each element of this concept over google and use books and journals related to this topic. Then, next steps are collected terms which relevance to research philosophy, methodologies and methods and also counted how many papers for the term. Fourthly, the collected terms identified and categorized into Research Paradigms, Research Approaches, Research Methodologies, Research Methods, Way to conclusion and other. Final, from the steps above author conclude what are the challenges and the issues happening to this concept of E-Government in Indonesia seen through the services for citizens.

\section{Finding and Analysis}

In this section, the authors of this paper present classification of research philosophy and methodologies in E-Government area. The collected data will be classified into research paradigms, research approaches, research methodologies, research methods, way to conclusion and others also conclude what are the challenges and the issues happening to this concept of E-Government in Indonesia seen through the services for citizens.

The services for citizens of E-Government in Indonesia in this paper divided into 8 elements. Will explained below started from responsibility, website, description until challenges and issues of each element:

\begin{tabular}{|c|c|}
\hline \multicolumn{2}{|r|}{ Passport } \\
\hline $\begin{array}{l}\text { Responsibility } \\
\text { Website }\end{array}$ & $\begin{array}{c}\text { Central Government, Ministry of the Interior, Civil Registry and Migration Department } \\
\text { www.imigrasi.go.id }\end{array}$ \\
\hline Description & $\begin{array}{l}\text { Information and forms to download. Due to security issues (biometric data), a passport can } \\
\text { only be provided to the applicant upon his personal visit to the relevant local authority or } \\
\text { department [4]. }\end{array}$ \\
\hline Challenges & $\begin{array}{l}\text { The e-Service could be improved in case of modification of the related legislation where the } \\
\text { application for passport can be submitted online (including do payment) and deliver the } \\
\text { document to the citizens' address. }\end{array}$ \\
\hline Issues & website is often down due to so many users access the website at a time and not friendly user. \\
\hline \multicolumn{2}{|r|}{ Money and Charges } \\
\hline Responsibility & Ministry of Finance (Department of Customs and Tax Department) \\
\hline Website & https://www.kemenkeu.go.id/, www.beacukai.co.id \\
\hline $\begin{array}{l}\text { Description } \\
\text { Challenges }\end{array}$ & $\begin{array}{l}\text { The websites are designed to provide links to the relevant services/information. } \\
\text { each department should have national standardization in order to give same facilitate in } \\
\text { serving the citizens. }\end{array}$ \\
\hline Issues & $\begin{array}{l}\text { information provided by separate websites, all information about money and charges better in } \\
\text { one website not separated. }\end{array}$ \\
\hline
\end{tabular}

Figure 1. Travel (passenger rights, document you need).

\begin{tabular}{|c|c|}
\hline \multicolumn{2}{|c|}{$\begin{array}{l}\text { Health related services (interactive advice on the availability of services in different hospitals; appointments for } \\
\text { hospitals) }\end{array}$} \\
\hline Responsibility & Central Government, Ministry of Health \\
\hline Website & - \\
\hline Description & - \\
\hline Challenges & information and form to download \\
\hline Issues & planning stage \\
\hline \multicolumn{2}{|r|}{ Medical Costs (Reimbursement or Direct Settlement) } \\
\hline Responsibility & a \\
\hline Website & - \\
\hline Description & - \\
\hline Challenges & $\begin{array}{l}\text { Information and forms to download for application to obtain a medical card. With regard to } \\
\text { medical costs, no application for reimbursement is required as medical costs are charged } \\
\text { according to what the citizen is entitled to, i.e. medical card category. Depending on } \\
\text { entitlement status, medical costs for government medical services can vary from zero fees, to } \\
\text { reduced fees, to payment of full cost. }\end{array}$ \\
\hline Issues & planning stage \\
\hline
\end{tabular}


Figure 2. Health (Planned and Unplanned Healthcare).

\begin{tabular}{|c|c|}
\hline \multicolumn{2}{|r|}{ Job search services by labour offices } \\
\hline $\begin{array}{l}\text { Responsibility } \\
\text { Website }\end{array}$ & $\begin{array}{l}\text { Central Government, Ministry of Labour and Social Insurance, Department of Labour } \\
\text { http://indonesia.go.id, bursakerjadepnaker.com, bpjsketenagakerjaan.go.id }\end{array}$ \\
\hline Description & $\begin{array}{l}\text { Enables users to search the job vacancies database according to criteria matching their profile. } \\
\text { It also allows employers to publish and manage job vacancies. }\end{array}$ \\
\hline Challenges & $\begin{array}{l}\text { The system should be able accepts digital CVs, accessible by interested employers, the } \\
\text { website should have a facilitate to do registration by personally present proof of ID in order to } \\
\text { be provided with a username and password, this way should have given benefit to registered } \\
\text { users, so the users could receive and set up the interested information [16][3][2]. } \\
\text { the website only give information about job vacancy, citizens who want to apply the job } \\
\text { vacancy should visit the link they provided, and even citizens can registration insurance } \\
\text { through the website, the website is not full electronic some facilitation that government offer } \\
\text { should do in traditional ways. }\end{array}$ \\
\hline \multicolumn{2}{|r|}{$\begin{array}{l}\text { Work and retirement (Professional qualifications) } \\
\text { Legal information system (including information on the regulated professions) }\end{array}$} \\
\hline $\begin{array}{l}\text { Responsibility } \\
\text { Website }\end{array}$ & $\begin{array}{c}\text { Several stakeholders } \\
\text { www.dikti.go.id, www.hukumonline.com, www.kemenkumham.go.id, } \\
\text { www.bisnisindonesiagroup.com }\end{array}$ \\
\hline Description & $\begin{array}{l}\text { Depending on the profession, this information is provided by the relevant stakeholder in } \\
\text { Indonesia [15][10][11][1]. Additionally, information on Professional qualifications can be } \\
\text { found on the Indonesian Business Portal which provides comprehensive information relating } \\
\text { to the procedures and formalities required for the access to, and the exercise of, service } \\
\text { activities in Indonesia }\end{array}$ \\
\hline Challenges & $\begin{array}{c}\text { online business in one portal below Indonesian government, economic growth and smart } \\
\text { consumers. }\end{array}$ \\
\hline Issues & $\begin{array}{l}\text { the mind-set of entrepreneurship is still very low, the rate of business collapse is high and not } \\
\text { clear about the value being defended since many local products are collapse }\end{array}$ \\
\hline \multicolumn{2}{|r|}{$\begin{array}{l}\text { Work and retirement (Taxes, unemployment and benefits) } \\
\text { Income taxes: declaration, notification of assessment }\end{array}$} \\
\hline Responsibility & Central Government, Ministry of Finance, Tax Departme \\
\hline Website & \\
\hline Description & $\begin{array}{l}\text { The efiling system allows taxpayers - natural persons and businesses/partnerships - to submit } \\
\text { initial tax returns electronically. The income tax declaration is pre-filled with the taxpayer's } \\
\text { relevant info such as name, address, correspondence address, contact details and taxpayer ID. }\end{array}$ \\
\hline Challenges & $\begin{array}{l}\text { not every citizen can use this system to submit their tax reports due to daily skill to use such } \\
\text { as computer and website, need a facilitation to solve this kind of problem }\end{array}$ \\
\hline Issues & website is often down due to so many users access the website at a time and not friendly user \\
\hline \multicolumn{2}{|c|}{$\begin{array}{c}\text { Work and retirement (Unemployment benefits (Standard procedure to obtain replacement income in case of } \\
\text { unemployment)) }\end{array}$} \\
\hline Responsibility & $\begin{array}{c}\text { Central Government, Ministry of Labour and Social Insurance, Social Insurance } \\
\text { Department }\end{array}$ \\
\hline Website & - \\
\hline Description & - \\
\hline Challenges & Creating jobs and entrepreneurship \\
\hline Issues & $\begin{array}{l}\text { Central Bureau of Statistics recorded open unemployment rate decreased in February } 2017 \\
5.33 \%\end{array}$ \\
\hline
\end{tabular}

Figure 3. Work and retirement (working abroad, finding a job abroad, retiring abroad). 


\section{Driver's Licence}

\begin{tabular}{|c|c|}
\hline Responsibility & $\begin{array}{c}\text { Central Government, Ministry of Transport, Communications and Works, Road Transport } \\
\text { Department }\end{array}$ \\
\hline Website & sim.korlamtas.polri.go.id \\
\hline Description & $\begin{array}{l}\text { Personal submission of documents to the website is required for obtaining the licence. The } \\
\text { site contains information, forms to fill and offers some online features. For example, } \\
\text { candidate drivers are given the option to select the date, time and place of their test via the } \\
\text { Internet [17] }\end{array}$ \\
\hline $\begin{array}{l}\text { Challenges } \\
\text { Issues }\end{array}$ & $\begin{array}{c}\text { delivery channels for the service, online payment, and available in every city in Indonesia } \\
\text { only available in certain big cities }\end{array}$ \\
\hline & $\begin{array}{l}\text { Vehicles (Insurance) } \\
\text { Third-Party Insurance }\end{array}$ \\
\hline Responsibility & Road Transport Department \\
\hline Website & - \\
\hline Description & - \\
\hline Challenges & $\begin{array}{l}\text { The Indonesian government must require every vehicle owner to participate in insurance and } \\
\text { set insurance costs, because the cost is getting higher nowadays }\end{array}$ \\
\hline Issues & under private parties \\
\hline \multicolumn{2}{|r|}{$\begin{array}{c}\text { Vehicles (Registration) } \\
\text { Car registration (new, used, imported cars) }\end{array}$} \\
\hline Responsibility & $\begin{array}{c}\text { Central Government, Ministry of Transport, Communications and Work, Department of Road } \\
\text { Transport }\end{array}$ \\
\hline Website & korlantas.polri.go.id/stnk \\
\hline Description & The site gives information for car regis \\
\hline Challenges & $\begin{array}{l}\text { offers services for the registration of motor vehicles and motor bikes. For new cars, the entire } \\
\text { process can be completed online, including payments. Registration of vehicles can also be } \\
\text { made via intermediaries, such as authorised car dealers and importers }\end{array}$ \\
\hline Issues & only information provided through this website \\
\hline
\end{tabular}

Figure 4. Vehicles (Driving Licence).

\begin{tabular}{|c|c|}
\hline \multicolumn{2}{|r|}{ Child Allowances } \\
\hline Responsibility & Central Government, Ministry of Finance, Grants and Benefits Service \\
\hline Website & - \\
\hline Description & - \\
\hline Challenges & $\begin{array}{c}\text { Article } 34 \text { paragraph (1) of the } 1945 \text { Constitution states that "poor and abandoned children } \\
\text { are kept by the state" }\end{array}$ \\
\hline Issues & The number of street children in 2015 as many as 33,400 children spread in 16 provinces \\
\hline \multicolumn{2}{|r|}{ Certificates (Birth, Marriage): Request and Delivery } \\
\hline $\begin{array}{l}\text { Responsibility } \\
\text { Website }\end{array}$ & $\begin{array}{c}\text { Central Government, Ministry of the Interior, Civil Registry and Migration Department } \\
\text { www.dukcapil.kemendagri.go.id }\end{array}$ \\
\hline Description & Information and forms to fill [5] \\
\hline $\begin{array}{l}\text { Challenges } \\
\text { Issues }\end{array}$ & $\begin{array}{l}\text { delivery channels for the service, online payment, and available in every city in Indonesia } \\
\text { depend on the city, only available in certain big cities }\end{array}$ \\
\hline & Figure 5. Family (Children, Couples). \\
\hline
\end{tabular}




\section{Consumer Protection}

\begin{tabular}{|c|c|}
\hline Responsibility & $\begin{array}{c}\text { Competition and Consumer Protection Service, Ministry of Energy, Commerce, Industry and } \\
\text { Tourism, Indonesian Consumers' Union and Quality of Life }\end{array}$ \\
\hline Website & ylki.or.id/hak-konsumen \\
\hline Description & $\begin{array}{c}\text { This website allows the consumers to fill in an online form in order to submit a complaint and } \\
\text { find information regarding their rights as consumers [28]. }\end{array}$ \\
\hline Challenges & $\begin{array}{l}\text { Centralized ownership, Implementation of laws and Communications for democratic } \\
\text { governance }\end{array}$ \\
\hline Issues & $\begin{array}{l}\text { Transparency, fair treatment, reliability, confidentiality and data security, and } \\
\text { simple, fast, and affordable settlement of user disputes } \\
\text { Consumers (Energy supply) }\end{array}$ \\
\hline & Living Facilities and Energy \\
\hline Responsibility & Electricity Authority of Indonesia \\
\hline Website & www.bumn.go.id/pln \\
\hline Description & information about electricity only [25] \\
\hline Challenges & $\begin{array}{l}\text { This website should allow the consumers to fill in an online form in order to submit a } \\
\text { complaint and find information regarding their rights as consumers }\end{array}$ \\
\hline Issues & high price, monopoly company \\
\hline
\end{tabular}

Figure 6. Consumers (Shopping (Your rights), Unfair Treatment). 
Announcement of moving (change of address)

\begin{tabular}{|c|c|}
\hline Responsibility & Central Government, Ministry of Interior, Civil Registry and Migration Department \\
\hline Website & www.dukcapil.kemendagri.go.id \\
\hline Description & Information only $[5]$ \\
\hline Challenges & all data changed provided by online \\
\hline Issues & the queue is too long to change the status of change address only. \\
\hline \multicolumn{2}{|r|}{ Certificates (Birth, Marriage): Request and Delivery } \\
\hline Responsibility & Central Government, Ministry of the Interior, Civil Registry and Migration Department \\
\hline Website & www.dukcapil.kemendagri.go.id \\
\hline Description & Information and forms to fill [5] \\
\hline Challenges & delivery channels for the service, online payment, and available in every city in Indonesia \\
\hline Issues & depend on the city, only available in certain big cities \\
\hline \multicolumn{2}{|r|}{ Criminal Record Certificate } \\
\hline Responsibility & Indonesian Police \\
\hline Website & https://www.polri/go.id \\
\hline Description & Physical presence is required therefore the service is not online [18] \\
\hline Challenges & how to preserve the origin record \\
\hline Issues & integrating from traditional way to modern way by technology \\
\hline \multicolumn{2}{|r|}{ Residence (and other) formalities (Declaration to the police (e.g. in case of theft)) } \\
\hline Responsibility & Central Government, Indonesian Police \\
\hline Website & https://www.polri/go.id \\
\hline Description & $\begin{array}{l}\text { Information only, no online declaration possible. According to current legislation, citizens must declare crimes, such } \\
\text { as theft, in person [18] }\end{array}$ \\
\hline Challenges & should improve the services \\
\hline Issues & long procedures to do \\
\hline \multicolumn{2}{|r|}{ Housing (building and housing, environment) } \\
\hline Responsibility & Central Government, Ministry of the Interior, Town Planning and Housing Department \\
\hline Website & dcktrp.jakarta.go.id \\
\hline Description & $\begin{array}{l}\text { Information and forms to fill. The related procedure involves a number of authorities. An application for a building } \\
\text { permission is initially delivered to the relevant municipality or district administration office of the Ministry of the } \\
\text { Interior [23] }\end{array}$ \\
\hline Challenges & $\begin{array}{l}\text { The integrated information system is expected to be a powerful tool for the upgrading of the services offered by } \\
\text { the Department, with purpose that of improvement in the bureaucratic procedures as well as of the average } \\
\text { response time to citizens' requests, and therefore the better and more effective public service }\end{array}$ \\
\hline Issues & available for Jakarta only \\
\hline \multicolumn{2}{|r|}{ Passport } \\
\hline Responsibility & Central Government, Ministry of the Interior, Civil Registry and Migration Department \\
\hline Website & www.imigrasi.go.id \\
\hline Description & $\begin{array}{l}\text { Information and forms to download. Due to security issues (biometric data), a passport can only be provided to the } \\
\text { applicant upon his personal visit to the relevant local authority or department [4]. }\end{array}$ \\
\hline Challenges & $\begin{array}{l}\text { The e-Service could be improved in case of modification of the related legislation where the application for passport } \\
\text { can be submitted online (including do payment) and deliver the document to the citizens' address. }\end{array}$ \\
\hline Issues & website is often down due to so many users access the website at a time and not friendly user. \\
\hline \multicolumn{2}{|r|}{ Participation in Elections } \\
\hline Responsibility & Ministry of Interior, Central Election Service \\
\hline Website & - \\
\hline Description & - \\
\hline Challenges & planned in 2019 \\
\hline Issues & not yet \\
\hline
\end{tabular}

Figure 7. Residence (and other) Formalities (Document and Formalities). 
Enrolment in higher education/university

\begin{tabular}{|c|c|}
\hline \multirow{3}{*}{$\begin{array}{l}\text { Responsibility } \\
\text { Website } \\
\text { Description }\end{array}$} & \multirow[b]{2}{*}{$\begin{array}{l}\text { Central Govemment, higher edueation institutions, ministry of Education and Culture } \\
\text { www.kemdikbud.go.id, dikti.go.id }\end{array}$} \\
\hline & \\
\hline & all about schools and universities information are available [14][15] \\
\hline $\begin{array}{l}\text { Challenges } \\
\text { Issues }\end{array}$ & $\begin{array}{l}\text { c-learning, e-education, quality of teachers, quality of education, equity of education, relevance of education } \\
2.5 \text { million Indonesian children are not able to enjoy continuing education as many as } 600 \text { thousand primary school-age } \\
\text { children and } 1.9 \text { million children of Junior High School age }\end{array}$ \\
\hline \multicolumn{2}{|r|}{ Public libraries (availability of catalogues, search tools) } \\
\hline Responsibility & Central Government, Local Govemment \\
\hline Website & www.perpusnas.go.id \\
\hline Description & $\begin{array}{l}\text { Some libraries provide catalogues which can locate holders and allow electronic reservations. For online public libraries, } \\
\text { which offer electronic reservations, prior registration of users is required [24] }\end{array}$ \\
\hline Challenges & e-books, iCentre in every school and university in Indonesia \\
\hline Issues & network for internet in Indonesia \\
\hline \multicolumn{2}{|r|}{ Student grants } \\
\hline Responsibility & Central Government, Ministry of Finance, Grants and Benefice Service \\
\hline Website & simbelmawa.ristekdikti.go.id, belmawa.ristekdikti.go.id, www.Jpdp.kemenkeu.go.jd \\
\hline Description & Information and forms to download $[27][26]$ \\
\hline Challenges & develop student creativity \\
\hline Issues & long procedures \\
\hline \multicolumn{2}{|r|}{$\begin{array}{l}\text { Education and youth (Traineeship, volunteering) } \\
\text { Voluntary social involvement I }\end{array}$} \\
\hline Responsibility & Central Government, Office of the Commissioner on Volunteerism and NGOs \\
\hline Website & knpipondokmelati.blogspot.com \\
\hline Description & $\begin{array}{l}\text { The Commissioner's office supports voluntary initiatives that encourage the active participation of citizens, especially the } \\
\text { youth, in environmental awareness issues, education, culture, sport, etc., always respecting the autonomy and independence } \\
\text { of voluntary and non-govemmental organizations [21] }\end{array}$ \\
\hline Challenges & $\begin{array}{l}\text { The website of the Commissioner on Volunteerism and NGOs should allow eitizens to apply online for becoming volunteers } \\
\text { and provides information regarding the activities planned (current/future) under the supervision of the Commissioner for } \\
\text { Voluntecrism and NGOs }\end{array}$ \\
\hline Issues & many bad issues came from this committee such as demo of labours in May 2017 \\
\hline \multicolumn{2}{|r|}{ Voluntary social involvement II } \\
\hline Responsibility & Youth Board of Indonesia \\
\hline Website & anarchoida.blogspot.co.id \\
\hline Description & no information available [22] \\
\hline Challenges & $\begin{array}{l}\text { The youth of Indonesia should be acknowledging the importance of volunteerism not only on the personal development of } \\
\text { young people but also on the cultivation of collective consciousness and social solidarity developed a "Youth Volunteer }\end{array}$ \\
\hline Issues & $\begin{array}{l}\text { Team" in order to actively contribute in this way in the promotion of voluntecrism among young people } \\
\text { Indifference to the surrounding environment, lack of understanding of the meaning of tolerance and diversity, tends to } \\
\text { exclusively bring young people into the problems and problems of today's teenagers }\end{array}$ \\
\hline \multicolumn{2}{|r|}{$\begin{array}{l}\text { Education and youth (Researches) } \\
\text { Information and assistance to researchers }\end{array}$} \\
\hline Responsibility & Indonesia \\
\hline Website & www.dikti.go.id \\
\hline Deseription & $\begin{array}{l}\text { Ministry of Research, Technology and Higher Education provides information and assistance to mobile researchers - by } \\
\text { means of the web portal and with the support of our national Indonesia Service Centres. The portal contains practical } \\
\text { information concerning professional and daily life, as well as information on job and funding opportunities [15] }\end{array}$ \\
\hline Challenges & increase the rate of research \\
\hline Issues & long and unclear procedures \\
\hline
\end{tabular}

Research funding support Research Promotion Foundation (RPF) (currently N/A)

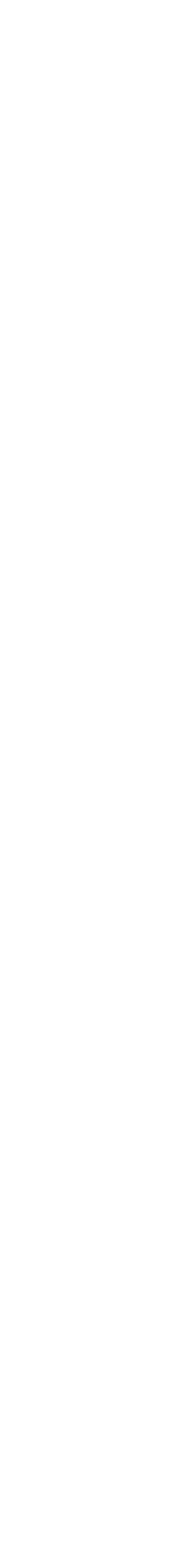




\section{Conclusion}

From the above analysis discussing about Travel, Work and Retirement, Vehicles, Residence formalities, Education and Youth, Health, Family Consumers, there are some services that are not yet available and are not yet in focus or are still in the planning stage in e-government in Indonesia: Work and retirement (Unemployment benefits (Standard procedure to obtain replacement income in case of unemployment)), Vehicles (Insurance) Third-party insurance, Residence (and other) formalities (Election Abroad) Participation in elections, health and Family (Children, couples) Child allowances.

Services for citizens in e-government is one of the most important things in e-government because the main user in e-government is citizens itself. For that, the government of Indonesia should be more focused at least to the 8 elements mentioned above.

\section{References}

1. Purnamasari N. E-Government System dalam Pelayanan Publik oleh Nurul Purnamasari Kompasiana.com [Internet]. Kompasiana. 2015. Available from: https://www.kompasiana.com/nurulpurnama07/e-government-system-dalam-pelayananpublik_5512a8bf813311476cbc601f

2. $\quad$ European Commission. Cyprus 03 36. 2016. 